\title{
Effect of Estrogen on Serum Total and Free Thyroxine and Triodothyronine in a Thyroxine-binding Globulin Deficient Family
}

\author{
Toshiro Sakurada, Toru Yamaguchi, Makiko Yamamoto, \\ Reiko Demura, Mitsuyasu Aida, Seiju Onodera, Katsumi \\ Yoshida, Shintaro SaIto, Hiroshi Ohuchi* and Shozo \\ MinaKuCHI* \\ Department of Internal Medicine and Department of Surgery,* \\ Tohoku University School of Medicine, Sendai
}

\begin{abstract}
Sakurada, T., Yamagdchi, T., Yamamoto, M., Demura, R., Aida, M., Onodera, S., Yoshida, K., Satto, S., Онuchi, H. and Minakuchi, S. Effect of Estrogen on Serum Total and Free Thyroxine and Triiodothyronine in a Thyroxinebinding Globulin Deficient Family. Tohoku J. exp. Med., 1974, 112 (1), 35-46 - In a family with $\mathrm{X}$-chromosome-linked inheritance of thyroxine $\left(\mathrm{T}_{4}\right)$-binding globulin (TBG) deficiency, serum free $\mathrm{T}_{4}$ values were low in three of four members, but free triiodothyronine $\left(T_{3}\right)$ values were normal in all four of them. Binding capacities of $\mathrm{T}_{4}$-binding prealbumin (TBPA) were high in three of four members. In the propositus, a 47-year-old male, whose $\mathrm{T}_{4}$-binding capacity of TBG was null, half-time of serum $\mathrm{T}_{4}$ was shortened, turnover rate, distribution space and clearance rate all increased, extrathyroidal organic iodine pool decreased and degradation rate of $\mathrm{T}_{4}$ was unchanged compared with normal values. While half-time of his serum $\mathrm{T}_{3}$ was prolonged, turnover rate, extrathyroidal pool and degradation rate of $T_{3}$ decreased, and $T_{3}$ distribution space and clearance rate increased compared with normal values. When $0.24 \mathrm{mg}$ of ethinylestradiol-3methylester was administered daily by mouth to the propositus for 1 month, halftime of serum $T_{4}$ was prolonged, total $T_{4}$ increased and $T_{4}$-binding capacity of TBPA decreased but free $T_{4}, T_{4}$-binding capacity of $T B G$ and the degradation rate of $T_{4}$ were unchanged. Meanwhile half-time of his serum $T_{3}$ was shortened, total and free $T_{3}$ levels and degradation rate of $T_{3}$ increased. $-T_{3}$ radioimmunoassay; estrogen; free $\mathrm{T}_{3}$ and $\mathrm{T}_{4}$; TBG-deficiency
\end{abstract}

The first euthyroid man with deficient TBG was reported by Tanaka and Starr (1959 a). In the present paper, the metabolism of $T_{4}$ and $T_{3}$ and binding capacities of TBG and TBPA and the effect of estrogen on them are studied in a TBG-deficient family.

The case studied was: H.T., 47-year-old man, an office employee.

Present illness: There were family histories of hepatoma and hypertension. In May 1969, he was found to have albuminuria and hypertension, and admitted to a hospital for about a month. In September, he was readmitted to the hospital for one month for the treatment of Raynaud's disease. In June 1971, he complained of palpitation and fatigue. Because the resin sponge ${ }^{131} \mathrm{I}-\mathrm{T}_{3}$ uptake value

Received for publication, July 21, 1973. 
was abnormally high, he was thought to have hyperthyroidism and was treated with antithyroid drug for two months. In September 1971, he was admitted to the Surgery Department of the Tohoku University Hospital for the treatment of Raynaud's disease, and received a bilateral lumbar sympathetic ganglionectomy. After the operation, he became free from symptoms, but was referred to our clinic for the examination of hypertension in October. No excessive sweating, shortness of breath and loss of weight were noticed.

Physical examinations: His height was $140.7 \mathrm{~cm}$ and weight $40.5 \mathrm{~kg}$, somewhat smaller than normal stature, but he was well developed and nourished. His blood pressure was $130 / 90 \mathrm{mmHg}$, pulse rate was $82 / \mathrm{min}$ and regular. The skin was normally moist and no edema was observed. No signs of the ophthalmopathies of Graves' disease were noticed. The thyroid gland was not palpable and no murmur was heard on it. The heart and the lungs were normal by the physical and radiological examinations. There were operation scars in both lumbar regions. Fine tremor of fingers was observed.

Laboratory findings (Table 1): Routine laboratory findings were within normal limits except for a slightly low value of serum iron-binding capacity. The funduscopic examination showed $\mathrm{KW}-1$ grade.

TABLE 1. Laboratory findings

\begin{tabular}{|c|c|}
\hline Urine and stool: no abnormal findings & Serum total protein: $7.1 \mathrm{~g} / 100 \mathrm{ml}$ \\
\hline E.S.R.: $12 \mathrm{~mm} / \mathrm{hr}$ & Albumin $\quad 63.8 \%$ \\
\hline RBC: $443 \times 10^{4}, 14.7 \mathrm{~g} / 100 \mathrm{ml}, \mathrm{WBC}: 6,200$ & $a_{1}$-globulin \\
\hline Differential count: no abnormalities & $\alpha_{2}$-globulin \\
\hline Serologic test for syphilis: negative & $\beta$-globulin \\
\hline Fasting blood sugar: $110 \mathrm{mg} / 100 \mathrm{ml}$ & $\gamma$-globulin $\quad 14.0 "$ \\
\hline Serum total cholesterol: $225 \mathrm{mg} / 100 \mathrm{ml}$ & \multirow{2}{*}{ Liver function tests: no abnormal findings } \\
\hline Serum electrolytes: & \\
\hline $\mathrm{Na} 142, \mathrm{~K} 4.6, \mathrm{Cl} 103 \mathrm{mEq} / \mathrm{L}$ & \\
\hline $\mathrm{Ca} 10.4, \mathrm{P} 3.0 \mathrm{mg} / 100 \mathrm{ml}$, Fe $115 \mu \mathrm{g} / 100 \mathrm{ml}$, & \\
\hline
\end{tabular}

Endocrinological examinations (Table 3): Histamine test was negative. Urinary 17-OHCS, estrogen and catecholamine values were all within normal limits. Binding capacity of corticosteroid-binding globulin in the serum was normal.

Thyroid function tests (Table 3): Basal metabolic rate (BMR) and thyroidal 24hour uptake of ${ }^{131} \mathrm{I}$ were normal, but resin sponge ${ }^{131} \mathrm{I}-\mathrm{T}_{3}$ uptake (Abbott Co.) was extremely high. Serum total $\mathrm{T}_{4}$, measured by Tatrasorb Kit (Abbott Co.) was low. The elutable fraction of $\mathrm{T}_{4}$, measured by microcolumn chromatography of Sephadex G-25 (Sakurada et al. 1969) corresponding to percent of free $\mathrm{T}_{4}$ (Sterling and Hegedus 1962) was high and the calculated serum free $\mathrm{T}_{\mathbf{4}}$ was low. Total serum $\mathrm{T}_{3}$ measured by radioimmunoassay (Sakurada et al. 1973) was low, but the elutable fraction of $\mathrm{T}_{3}$ (Sakurada et al. 1969) corresponding to percent of free $\mathrm{T}_{\mathbf{3}}$ (Oddie et al. 1971) was high and calculated serum free $\mathrm{T}_{3}$ was normal. Plasma thyroid-stimulating hormone (TSH) levels measured by radioimmunoassay 
TABLE 2. Endocrinological findings

\begin{tabular}{lc}
\hline Urine 17-OHCS & $3.42 \mathrm{mg} / \mathrm{m}^{2} /$ day \\
Urine 17-KS & $5.6 \mathrm{mg} /$ day \\
Serum cortisol & $16.7 \mu \mathrm{g} / 100 \mathrm{ml}$ \\
Binding capacity of & $18.1 \mu \mathrm{g} / 100 \mathrm{ml}$ \\
$\quad$ transcortin & $37.8 \mu \mathrm{g} / 100 \mathrm{ml}$ \\
Urine estrogens & $13.3 \mu \mathrm{g} / 100 \mathrm{ml}$ \\
$\quad$ estron & $10.5 \mu \mathrm{g} / 100 \mathrm{ml}$ \\
$\quad$ estradiol & $14.0 \mu \mathrm{g} / 100 \mathrm{ml}$ \\
$\quad$ estriol & $0.18 \mathrm{mg} /$ day \\
Urine pregnanediol & $2.1 \mu \mathrm{g} /$ day \\
Urine adrenaline & $14.5 \mu \mathrm{g} /$ day \\
Urine noradrenaline & 14.5 \\
Histamin test & Negative \\
\hline
\end{tabular}

TABLE 3. Thyroid function tests

\begin{tabular}{ll}
\hline BMR & $-2.5 \%$ \\
24-hour uptake of ${ }^{131} \mathrm{I}$ & $16 \%$ \\
Resin-sponge ${ }^{131} \mathrm{I}^{-} \mathrm{T}_{3}$ & $60 \%$ \\
$\quad$ uptake (Triosorb kit) & \multicolumn{1}{c}{$\%$} \\
PBI & $2.8 \mu \mathrm{g} / 100 \mathrm{ml}$ \\
Serum thyroxine & $2.5 \mu \mathrm{g} / 100 \mathrm{ml}$ \\
$\quad$ (Tetrasorb kit) & Positive \\
TSH test & 0 \\
Tanned-red-cell $\quad$ hemagglutination test & 0 \\
\hline
\end{tabular}

(Demura et al. 1969) and the TSH response to synthetic thyrotropin-releasing hormone (TRH) were nearly normal. Thyroidal ${ }^{131} \mathrm{I}$ uptake responded to the intramuscular injection of TSH (10 U.S.P. per day) for 3 days. $\mathbf{T}_{4}$-binding capacity of TBG, measured by the method of Tanaka and Starr (1959 b) (reverse-flow paper electrophoresis, barbital buffer, $\mathrm{pH} 8.6$ ), was null.

As shown in Table 4 and Fig. 1, his younger brother (M.T.) was proved to be TBG deficient and his mother (S.T.) and eldest sister (I.T.) to have a decreased TBG. Serum total $T_{4}$ in Case M.T. was low. Serum free $T_{4}$ in Case S.T. was normal, but those in Cases M.T. and I.T. were low. Serum total $\mathrm{T}_{\mathbf{3}}$ in Case M.T. was low, but serum free $T_{3}$ was normal in all four members. When $T_{4}$-binding capacity of TBPA was measured by the method of the present author (Sakurada et al. 1967) (polyacrylamide gel electrophoresis, borate buffer, $\mathrm{pH} 8.2$ ) and by the

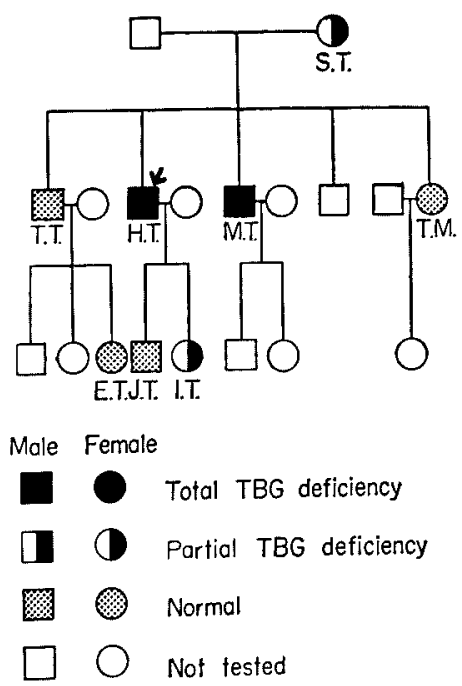

Fig. 1. Pedigree of the present family (the arrow indicates the propositus, H.T.). 
TABLE 4. Thyroid function tests of a TBG-deficient

\begin{tabular}{|c|c|c|c|c|c|}
\hline & & \multicolumn{2}{|c|}{ Propositus (H.T.) } & \multicolumn{2}{|c|}{ T.T. } \\
\hline & & \multicolumn{4}{|c|}{ Administration of estrogen } \\
\hline & & Before & After & Before & After \\
\hline RSU & $(\%)$ & 60.0 & 54.0 & 24.6 & 18.4 \\
\hline Total $\mathbf{T}_{4}$ & $(\mu \mathrm{g} / 100 \mathrm{ml})$ & 2.50 & 2. 75 & 11.0 & 12.25 \\
\hline $\mathrm{EF}$ of $\mathrm{T}_{4}$ & $\left(\times 10^{-4}\right)$ & 6.65 & 4. 65 & 4.65 & 3.53 \\
\hline Free $T_{4}$ & $(\mathrm{ng} / 100 \mathrm{ml})$ & 1. 66 & 1.28 & 5. 10 & 5.30 \\
\hline Total $\mathrm{T}_{3}$ & $\left(\mathrm{ng} / 10_{0} \mathrm{ml}\right)$ & 48 & 70 & 107 & 218 \\
\hline EF of $\mathrm{T}_{3}$ & $\left(\times 10^{-3}\right)$ & 6.43 & 8.88 & 3.72 & 1.74 \\
\hline Free $\mathrm{T}_{3}$ & $(\mathrm{pg} / 100 \mathrm{ml})$ & 309 & 622 & 398 & 379 \\
\hline $\mathrm{TBG} *$ & $\left(\mathrm{~T}_{4} \mu \mathrm{g} / 100 \mathrm{ml}\right)$ & 0 & 0 & 22.8 & 34.2 \\
\hline TBPA $\dagger$ & $\left(\mathrm{T}_{4} \mu \mathrm{g} / 100 \mathrm{ml}\right)$ & 421 & 315 & 330 & 232 \\
\hline $\mathrm{TBPA}_{+}^{+}$ & $\left(\mathrm{T}_{4} \mu \mathrm{g} / 100 \mathrm{ml}\right)$ & 310 & 229 & 240 & 215 \\
\hline
\end{tabular}

* Reverse-flow paper electrophoresis (barbital buffer, pH 8.6)

$\ddagger$ Reverse-flow paper electrophoresis (glycine acetate buffer, $\mathrm{pH} 8.6$ )

TABLE 5. Effect of estrogen on $T_{4}$ kinetics of TBG-deficient (H.T.) and normal (T.T.) subjects

\begin{tabular}{|c|c|c|c|c|c|c|}
\hline & $\mathrm{H}$. & & $\mathbf{T}$ & & \multirow{3}{*}{$\begin{array}{l}\text { Normal } \\
\text { range }\end{array}$} & \multirow{3}{*}{$\begin{array}{l}\text { Ingbar's } \\
\text { euthyroid }\end{array}$} \\
\hline & \multicolumn{4}{|c|}{ Administration of estrogen } & & \\
\hline & Before & After & Before & After & & \\
\hline \multirow{3}{*}{$\begin{array}{l}\mathrm{T}_{4} \text { half-time } \\
\text { Turnover rate } \\
\mathrm{T}_{4} \text { distribution } \\
\text { space }\end{array}$} & 3.3 & 3.6 & 7. 0 & 8.8 & $5.7 \sim 7.2$ & $6.6 \pm$ \\
\hline & 21.0 & 19.3 & 9.9 & 7.9 & $9.6 \sim 12.2$ & $10.6 \pm \quad 0.9$ \\
\hline & 16. 3 & 16.4 & 9.6 & 9.9 & $6.4 \sim 10.1$ & $9.4 \pm \quad 2.0$ \\
\hline \multirow{3}{*}{$\begin{array}{ll}\text { Extrathyroidal organic } \\
\text { iodine pool } \quad(\mu \mathrm{gI}) \\
\text { Clearance rate } \quad(\mathrm{L} / \text { day }) \\
\text { Degradation rate }(\mu \mathrm{gI} / \text { day })\end{array}$} & 266 & 295 & 690 & 792 & $6 \sim 690$ & $508 \pm 146$ \\
\hline & 3.42 & 3.17 & 0.95 & 0.78 & $0.78 \sim 1.08$ & $1.0 \pm 0.25$ \\
\hline & 55.9 & 56.9 & 68.3 & 62.6 & $55.1 \sim 68.3$ & $53.6 \pm 16.5$ \\
\hline
\end{tabular}

* Calculated from Ingbar's turnover rate

TABLE 6. Effect of estrogen on $T_{3}$ kinetics of

\begin{tabular}{|c|c|c|c|c|}
\hline & & \multicolumn{2}{|c|}{ H.T. } & T.T. \\
\hline & & \multicolumn{3}{|c|}{ Administration of estrogen } \\
\hline & & Before & After & Before \\
\hline $\mathrm{T}_{3}$ half-time & (hrs) & 26.4 & 22.8 & 21.6 \\
\hline Turnover rate & $(\% /$ day $)$ & 63 & 73 & 77 \\
\hline $\mathrm{T}_{3}$ distribution space & (L) & 42.8 & 42.9 & 34.2 \\
\hline Extrathyroidal $\mathrm{T}_{3}$ pool & $(\mu \mathrm{g})$ & 20.5 & 30.0 & 36.6 \\
\hline Clearance rate & (L/day) & 27.0 & 31.3 & 26.3 \\
\hline Degradation rate & ( $\mu \mathrm{g} / \mathrm{day})$ & 13.0 & 21.9 & 28.2 \\
\hline
\end{tabular}


family and effects of estrogen on them

M.T. S.T. I.T. J.T. T.M. E.T. $\quad \begin{gathered}\text { Normal } \\ \text { range }\end{gathered}$

\begin{tabular}{cccccccc}
\hline 53.5 & 42.6 & 44.0 & 26.0 & 26.4 & 22.0 & $25 \sim 40$ \\
2.3 & 7.2 & 5.8 & 8.2 & 9.2 & 9.0 & $5 \sim 15$ \\
8.40 & 4.54 & 2.83 & 3.91 & 3.16 & 3.92 & $3.6 \sim 6.4$ \\
1.93 & 3.27 & 1.64 & 3.20 & 2.91 & 3.53 & $2.0 \sim 3.5$ \\
47 & 87 & 120 & 90 & 98 & 111 & $70 \sim 180$ \\
- & 3.32 & 3.40 & 2.93 & 3.20 & 3.78 & $2.8 \sim 4.2$ \\
- & 289 & 408 & 264 & 314 & 420 & $260 \sim 450$ \\
0 & 4.0 & 8.6 & 26.5 & 22.8 & 29.4 & $15 \sim 30$ \\
353 & 331 & 378 & 363 & 326 & 302 & $260 \sim 330$ \\
341 & 262 & 270 & 290 & 254 & 275 & $220 \sim 280$ \\
\hline
\end{tabular}

$\dagger$ Polyacrylamide gel electrophoresis (borate buffer, pH 8.2)

method of Sterling and Tabachnick (1961) (reverse-flow paper electrophoresis, glycine acetate buffer, $\mathrm{pH}$ 8.6), the values in Cases H.T., M.T. and I.T. were high.

$T_{4}$-kinetics (Table 5): $\mathrm{T}_{4}$-kinetics in Case H.T. was studied by the method of Ingbar and Freinkel (1955). Half-time of the serum $\mathrm{T}_{4}$ was shortened, the turnover rate, distribution space and the clearance rate of $\mathrm{T}_{4}$ increased, but the degradation rate was within normal limits.

T3-kinetics (Table 6): $\mathrm{T}_{3}$-kinetics in Case H.T. was studied by the singleinjection method of Cavalieri et al. (1971). Half-time of the serum $\mathrm{T}_{3}$ was prolonged, the turnover rate and $\mathrm{T}_{3}$ distribution space increased, the extrathyroidal $\mathrm{T}_{4}$ pool decreased, the clearance rate unchanged and degradation rate decreased.

Effects of estrogen: The effects of the ethinylestradiol-3-methylester, $0.24 \mathrm{mg}$ of which were given orally every day for one month, were studied on the $\mathrm{T}_{4^{-}}$and $\mathrm{T}_{3}$-kinetics in Cases H.T. and T.T. (Tables 5 and 6 ).

As for $\mathrm{T}_{4}$-kinetics in both Cases of H.T. and T.T., the estrogen administration caused an increase in serum total $\mathrm{T}_{4}$, a prolongation of half-time and increase of

TBG-deficient (H.T.) and normal (T.T.) subjects

\begin{tabular}{lccc}
\hline & $\begin{array}{c}\text { Normal } \\
\text { range }\end{array}$ & $\begin{array}{c}\text { McConnon's } \\
\text { euthyroid }\end{array}$ & $\begin{array}{c}\text { Cavalieri's } \\
\text { euthyroid }\end{array}$ \\
\hline After & $20.4 \sim 21.6$ & - & $22.2 \pm 3.6$ \\
18.0 & $77 \sim 82$ & $68 \pm 2.9$ & - \\
92 & $26.9 \sim 34.2$ & $37.8 \pm 1.35$ & $-1 \pm 6.4$ \\
35.1 & $32.3 \sim 36.6$ & - & $27.2 \pm 7.1$ \\
76.5 & $26.3 \sim 28.9$ & $25.4 \pm 1.42$ & - \\
32.3 & $21.9 \sim 28.2$ & $57.3 \pm 2.29$ &
\end{tabular}


TABLE 7. Effect of oral administration of ethinylestradiol $(0.18 \sim 0.3 \mathrm{mg}$ per day for 7 days $)$ on serum total protein and its fractions

\begin{tabular}{|c|c|c|c|c|c|c|c|c|c|c|c|c|}
\hline \multirow{4}{*}{$\begin{array}{l}\text { Age } \\
\text { and } \\
\text { sex }\end{array}$} & \multicolumn{6}{|c|}{ Before estrogen administration } & \multicolumn{6}{|c|}{ After estrogen administration } \\
\hline & \multirow{3}{*}{$\begin{array}{l}\text { Serum } \\
\text { total } \\
\text { protein } \\
(\mathrm{g} / 100 \mathrm{ml})\end{array}$} & \multicolumn{5}{|c|}{ Percent of fractions $(\%)$} & \multirow{3}{*}{$\begin{array}{l}\text { Serum } \\
\text { total } \\
\text { protein } \\
(\mathrm{g} / 100 \mathrm{ml})\end{array}$} & \multicolumn{5}{|c|}{ Percent of fractions $(\%)$} \\
\hline & & \multirow{2}{*}{$\begin{array}{l}\text { Albu- } \\
\text { min }\end{array}$} & \multicolumn{4}{|c|}{ Globulin } & & \multirow{2}{*}{$\begin{array}{l}\text { Albu- } \\
\text { min }\end{array}$} & \multicolumn{4}{|c|}{ Globulin } \\
\hline & & & $\alpha_{1}$ & $\alpha_{2}$ & $\beta$ & $\gamma$ & & & $a_{1}$ & $a_{2}$ & $\beta$ & $\gamma$ \\
\hline \multicolumn{13}{|c|}{ Euthyroid } \\
\hline $28 \mathrm{f}$ & 7.2 & 55.3 & 5.3 & 15.1 & 11.5 & 12.8 & 8.4 & 59.9 & 3.4 & 15.5 & 11.1 & 10.1 \\
\hline $19 \mathrm{f}$ & 7.2 & 56.7 & 5.1 & 11.2 & 11.2 & 15.8 & 8.7 & 61.4 & 3. 6 & 9.6 & 11.0 & 14. 4 \\
\hline $24 \mathrm{f}$ & 7.2 & 54.1 & 5.7 & 10.5 & 10.1 & 19.6 & 9.4 & 61.0 & 2.9 & 11.9 & 9.7 & 14.5 \\
\hline \multicolumn{13}{|c|}{ Hyperthyroid } \\
\hline $36 \mathrm{f}$ & 7.3 & 50.5 & 3.5 & 11.0 & 10.5 & 24.5 & 8.0 & 60.3 & 3. 7 & 8.7 & 8.7 & 18.6 \\
\hline $43 \mathrm{f}$ & 7.0 & 55.3 & 3.8 & 8.7 & 9.1 & 23.1 & 7.4 & 66.7 & 2. 2 & 5.8 & 8.6 & 16.7 \\
\hline $30 \mathrm{f}$ & 7.4 & 52.6 & 5.5 & 11.0 & 8.8 & 22.1 & 8.2 & 59.9 & 5.1 & 9.1 & 9.1 & 16.8 \\
\hline $17 \mathrm{f}$ & 6.5 & 61.9 & 3.4 & 9.7 & 9.1 & 15.9 & 7.8 & 57.0 & 3.8 & 11.1 & 10.6 & 17.5 \\
\hline $49 \mathrm{~m}$ & 5.6 & 62.4 & 4. 0 & 8.0 & 9.6 & 16.0 & 7.8 & 57.4 & 3.8 & 9.8 & 10.4 & 18.6 \\
\hline $47 \mathrm{f}$ & 6.8 & 61.5 & 5.2 & 8.3 & 9.9 & 15.1 & 7.7 & 66.7 & 1.9 & 6.2 & 8.0 & 17.2 \\
\hline $18 \mathrm{~m}$ & 8.0 & 66.7 & 4.3 & 8.6 & 10.7 & 9.7 & 7.5 & 71.1 & 3.3 & 8.0 & 9.3 & 8.3 \\
\hline $36 \mathrm{f}$ & 6.0 & 56.5 & 4.7 & 10.7 & 10.3 & 18.4 & 8.2 & 58.3 & 4.1 & 12.3 & 8.9 & 16.4 \\
\hline $30 \mathrm{~m}$ & 6.8 & 68.3 & 2.8 & 6.7 & 7.8 & 14.4 & 6.8 & 62.7 & 3.5 & 8.0 & 9.7 & 16.1 \\
\hline $58 \mathrm{f}$ & 7.0 & 54.8 & 3.4 & 8.2 & 10.1 & 23.5 & 8.2 & 59.4 & 3.2 & 8.7 & 8.3 & 20.4 \\
\hline $43 \mathrm{f}$ & 6.2 & 60.4 & 4.0 & $9 . \dot{4}$ & 7.9 & 18.3 & 7.2 & 60.6 & 4. 1 & 9.0 & 9.2 & 17.1 \\
\hline $31 \mathrm{f}$ & 6.3 & 47.1 & 5.8 & 12.2 & 10.6 & 24.3 & 8.8 & 55.4 & 3.4 & 9.5 & 11.7 & 20.0 \\
\hline $45 \mathrm{f}$ & 6.8 & 60.5 & 4.2 & 9.0 & 11.9 & 14.4 & 7.6 & 68.4 & 2.1 & 7.8 & 9.2 & 12.5 \\
\hline \multicolumn{13}{|c|}{ Hypothyroid } \\
\hline $60 \mathrm{f}$ & 7.6 & 59.8 & 3.5 & 9.0 & 7.8 & 19.9 & 9.0 & 59.1 & 3.2 & 8.7 & 8.0 & 21.0 \\
\hline $37 \mathrm{f}$ & 7.7 & 64.5 & 1.9 & 8.4 & 7.9 & 17.3 & 8.2 & 64.5 & 2.1 & 8.4 & 8.0 & 17.0 \\
\hline $60 \mathrm{~m}$ & 7.4 & 50.9 & 3.4 & 12.0 & 12.4 & 21.2 & 8.0 & 56.7 & 4.4 & 8.5 & 10.0 & 20.4 \\
\hline Mean & 7.0 & 57.9 & 4. 2 & 9.9 & 9.9 & 18.2 & 8.0 & 61.4 & 3.4 & 9.3 & 9.0 & 16.5 \\
\hline s.p. & \pm 0.6 & $\pm 5.5=$ & \pm 1.0 & \pm 1.9 & \pm 1.4 & \pm 4.1 & \pm 0.6 & \pm 4.2 & \pm 0.8 & \pm 2.2 & \pm 1.6 & \pm 3.3 \\
\hline \multicolumn{13}{|c|}{ The present family } \\
\hline H.T. & 7.1 & 63.8 & 3.8 & 10.3 & 8.1 & 14.0 & 7.0 & 66.2 & 3.8 & 9.3 & 8.7 & 12.0 \\
\hline T.T. & 6.2 & 59.7 & 5.4 & 11.5 & 8.0 & 15.4 & 6.4 & 58.0 & 6.4 & 11.9 & 11.5 & 12.2 \\
\hline
\end{tabular}

turnover rate and extrathyroidal $\mathrm{T}_{4}$ pool, but there was no change in free $\mathrm{T}_{4}, \mathrm{~T}_{4}$ distribution space and degradation rate. $\mathrm{T}_{4}$-binding capacity of $\mathrm{TBG}$ did not change in Case H.T., but increased in Case T.T. $\mathrm{T}_{4}$-binding capacity of TBPA decreased in both of them.

As for $\mathrm{T}_{3}$-kinetics in both cases of H.T. and T.T., the serum total $\mathrm{T}_{3}$ increased, the half-time was shortened, the $\mathrm{T}_{3}$ distribution space unchanged, the turnover rate, extrathyroidal $\mathrm{T}_{3}$ pool, clearance rate and degradation rate increased after estrogen administration. Serum free $\mathrm{T}_{3}$ did not change in Case T.T., but increased in Case. H.T.

In three euthyroid, thirteen hyperthyroid and three hypothyroid patients, 
serum total protein was determined by a biuret method and fractions of serum protein were estimated by cellulose-acetate membrane electrophoresis (barbital buffer, $\mathrm{pH} 8.6$ ) before and after the oral administration of $0.18-0.3 \mathrm{mg}$ of ethinylestradiol-3-methylester per day for 7 days (Table 7). Mean values of total serum protein and the percent of albumin fraction tended to increase by estrogen administration.

\section{Discussion}

In regard to the $\mathrm{T}_{4}$ kinetics of the present case, the half-time was shortened, the fractional turnover rate and distribution space increased, but the extrathyroidal $\mathrm{T}_{4}$ pool was reduced, so degradation rate was normal as in the case reported by Ingbar (1961). The normal degradation rate of $\mathrm{T}_{4}$ in this case would account for the fact that the patient remained euthyroid even though his TBG was deficient.

It is assumed that, if serum TBG decreases, the percentage and absolute amount of serum free $\mathrm{T}_{4}$ increase (Rosenbaum et al. 1968). The increased free $\mathrm{T}_{4}$ causes a suppression of TSH secretion, accordingly the circulating $\mathrm{T}_{4}$ (protein bound iodine, $\mathrm{PBI}$ ) will decrease so as to restore the absolute amount of free $\mathrm{T}_{4}$ to normal, although the percentage may remain increased. Thus, the patient with decreased TBG is euthyroid with low PBI and normal free $T_{4}$. Indeed, PBI values in subjects with decreased TBG are reported to be low (Ingbar 1961; Nikolai and Robert 1969; Refetoff et al. 1972). But, if TSH secretion is suppressed, thyroidal uptake of ${ }^{131} \mathrm{I}$ is to be suppressed, too. However, except for the case of Beisel et al. (1962), cases with decreased TBG have not shown any decrease in thyroidal uptake of ${ }^{131} \mathrm{I}$. The TSH level in the present case, measured by radioimmunoassay, was high normal. And an intravenous administration of $500 \mu \mathrm{g}$ of synthetic TRH caused a response of plasma TSH. Therefore it may be presumed that there is not always hyposecretion of TSH in TBG-deficient subjects.

The serum free $T_{4}$ values in three of four members of the present family were lower than normal value. And free $\mathrm{T}_{4}$ values in euthyroid subjects with decreased TBG are observed to be normal or low (Cavalieri and Seale 1966; Bayley et al. 1969; Heinonen et al. 1970; Nusynowiz et al, 1971; Hennemann and Dolman 1971; Refetoff et al. 1972). On the other hand, serum free $\mathrm{T}_{4}$ values in euthyroid subjects with elevated TBG are reported to be normal or high (Katz and Oppenheimer 1963; Jones and Seale 1967; Shane et al. 1971; Thomson et al. 1972). Moreover, increase in serum free $T_{4}$ has been reported in normal individuals in response to stress such as surgical operations (Bernstein and Oppenheimer 1966). From these results, the authors would agree with Heinonen et al. (1970) and Thomson et al. (1972) who retain some doubts that serum free $\mathrm{T}_{4}$ is the main factor to control the thyroid metabolism.

$\mathrm{T}_{4}$-binding capacities of TBPA in three of four members of this family were higher than normal. Recent papers indicated that the $\mathrm{T}_{4}$-binding capacity of TBPA were high in 14-20 percent of the subjects with decreased TBG (Bayley et al. 1969; Nusynowiz et al. 1971; Refetoff et al. 1972). Heinonen et al. (1970) 
reported that a mean value of the $\mathrm{T}_{4}$-binding capacity of TBPA in subjects with decreased TBG was higher than normal. On the other hand, $\mathrm{T}_{4}$-binding capacity of TBPA are found to be low in many cases with increased TBG (Florsheim et al. 1962; Ingbar et al. 1964; Thomson et al. 1972). In the present case, $\mathrm{T}_{4}$-binding capacity of TBG was increased and that of TBPA was decreased by estrogen administration (Table 4). It is interesting that, when a binding capacity of TBP varies in the subjects with decreased or increased TBG, there is a reciprocal change in the $\mathrm{T}_{4}$-binding capacity of TBPA, while when a secretion of thyroid hormone changes in hyper- or hypothyroidism, the binding capacities of TBG and TBPA show concordant changes, both increasing in hyperthyroidism and decreasing in hypothyroidism (Cavalieri 1961; Sakurada et al. 1968). However, the change of binding capacity of TBPA is not always observed in the subjects with decreased or increased TBG, so that further studies are waited on this aspect.

TBPA is said to contribute significantly to the hormonal binding in vivo (Ingbar and Freinkel 1960), but other evidence suggests that it may not be so (Christensen and Litonjua 1961). In the present members with TBG deficiency, the serum total $T_{3}$ was low or low normal, but the serum free $T_{3}$ was normal in all. There may be a possibility of competition between $T_{4}$ and $T_{3}$ for binding sites of TBP other than TBG in TBG deficiency. The fact that free $\mathrm{T}_{3}$ was normal in the present case might be another reason why he was euthyroid, but free $\mathrm{T}_{3}$ did not increase so as to compensate sufficiently the deficit of serum free $T_{4}$.

Contrary to $\mathrm{T}_{4}$, half-time of $\mathrm{T}_{3}$ in the present case was longer than normal, but not so long as in the case reported by Bayley et al. (1969). This might be due to the difference of the method used for estimation; they counted the radioactivity of the plasma containing ${ }^{131} \mathrm{I}-\mathrm{T}_{3}$, but in our experiment, serum proteins were precipitated with trichloroacetic acid, the precipitate was extracted three times with acidbutanol and the butanol-extractable ${ }^{131} \mathrm{I}$ was determined as ${ }^{131} \mathrm{I}_{-} \mathrm{T}_{\mathbf{3}}$ (Cavalieri et al. 1971; McConnon et al. 1972). According to Woeber et al. (1970), half-time of $\mathrm{T}_{3}$ was prolonged when $T_{3}$ was administered intravenously to saturate TBG. Binding capacity of TBG in the subjects with decreased TBG is reported to be unsaturated (Kraemer and Wiswell 1968; Nikolai and Roberts 1969) and it seems likely that $\mathrm{T}_{4}$ and $\mathrm{T}_{3}$ compete for binding at the binding site of decreased TBG.

By estrogen administration, as Dowling et al. (1960) and Ingbar (1961) reported, turnover rate of $\mathrm{T}_{4}$ and extrathyroidal $\mathrm{T}_{4}$ pool increased, clearance rate of $\mathrm{T}_{4}$ decreased and degradation rate of $\mathrm{T}_{4}$ remained unchanged. After estrogen administration, $\mathrm{T}_{4}$-binding capacity of $\mathrm{TBG}$ was increased in Case T.T. but unchanged in Case H.T., while $\mathrm{T}_{4}$-binding capacity of TBPA was decreased in both cases. On the other hand, Braverman et al. (1971) reported that $\mathbf{T}_{4}$-binding capacity of TBPA was found to be increased by androgen administration.

As to the effects of estrogen on $\mathrm{T}_{3}$ kinetics, half-time was slightly shortened and serum total $\mathrm{T}_{3}$, turnover rate, extrathyroidal pool and degradation rate of $\mathrm{T}_{3}$ were increased in both Cases T.T. and H.T. as Zaninovich et al. (1969) observed in normal subject. 
As shown in Table 7, serum total protein and percent of albumin fraction tended to be increased by estrogen administration. Since the binding capacities of TBG and TBPA depend upon their respective protein concentrations (Oppenheimer et al. 1966; Sakurada et al. 1968; Levy et al. 1971), if concentration of albumin increases, the binding capacity of albumin for $T_{4}$ and $T_{3}$ might increase and this change of binding capacity may influence the amount of total and free $T_{4}$ and $T_{3}$. Especially, in cases of TBG deficiency like the present one, increase of serum total $\mathrm{T}_{\mathbf{3}}$ may partly be due to the increase of albumin fraction.

The decrease of concentration of serum albumin is observed in pregnancy as a result of blood dilution (Dickmann 1952), and the total $\mathrm{T}_{4}$ and $\mathrm{T}_{3}$ values in pregnant women are reported to increase in parallel with the increase of TBG (Hotellung and Sherwood 1971). Therefore, TBG may be related more closely to the increase of total $\mathrm{T}_{4}$ and $\mathrm{T}_{3}$ than albumin in pregnancy. It has been postulated that the increase of serum total $\mathrm{T}_{4}$ after estrogen administration is due to the shift of $\mathrm{T}_{4}$ from intracellular site to extrathyroidal site (Musa et al. 1969), which is contrary to the changes observed in the idiopathic TBG-deficiency (Cavalieri and Searle 1966) and in a decreased binding capacity of TBG after administration of diphenylhydantoin (Oppenheimer et al. 1967). Moreover, as estrogen is supposed to increase the TSH secretion (Adams and Maloof 1970), there is a possibility that the increased TSH may play a role in these changes.

Estrogen administration did not change the serum free $T_{3}$ level in Case T.T., but increased free $\mathrm{T}_{3}$ in the present case from 309 to $621 \mathrm{pg} / 100 \mathrm{ml}$ without causing hyperthyroidism. The reason why increased free $\mathrm{T}_{\mathbf{3}}$ did not cause hypermetabolism in the present case remains obscure. But there are interesting reports that thyrotoxicosis does not occur in pregnancy in spite of the increase of human chorionic thyrotropin (Hennen et al. 1969) and further, an increased serum free $\mathrm{T}_{4}$ does not always induce thyrotoxicosis (Katz and Oppenheimer 1963; Bernstein and Oppenheimer 1966; Thomson et al. 1972). In normal subjects, estrogen administration might not cause any change in serum free $T_{3}$, because the effects of estrogen on $\mathrm{T}_{3}$-binding capacity of TBP and those on $\mathrm{T}_{3}$-kinetics would cancel each other. In the present case, however, estrogen administration increased the serum free $T_{3}$ level probably by inducing competition between $T_{4}$ and $T_{3}$ for the binding site of TBP. Moreover, there might also be a competition for binding sites between $\mathrm{T}_{4}$ and $\mathrm{T}_{3}$ at intracellular site (Cavalieri et al. 1970). If $\mathrm{T}_{4}$ shifts from the intracellular site to the extracellular site when estrogen was administered, the residual $\mathrm{T}_{3}$ might be more easily metabolized and the degradation rate of $\mathrm{T}_{3}$ may increase.

Chromosome abnormality could not be found in the present case. As shown in Fig. 1, X-chromosome-linked inheritance was strongly suggested in the present family.

\section{Acknowledgment}

This research was conducted under the direction of Professors T. Torikai and K. Yoshinaga. 


\section{References}

1) Adams, L. \& Maloof, F.M. (1970) Effect of estrogen on the serum level of thyrotropic hormone in humans. J. clin. Invest., 49, 1 a, (abstract)

2) Bayley, T.A., Higgins, H.P., Row, V.V., James, W. \& Vidal, R. (1969) The metabolic significans of thyroxine-binding globulin; studies in a family with decreased thyroxine -binding globulin. Actr endocr. (Kbh.), 61, 137-150.

3) Beisel, L.C.W.R., Army, U.S., Zainal, H., Hane, S., DiRaimondo, V.C. \& Forsham, P.H. (1962) Low thyroidal iodine uptake with euthyroidism associated with deficient thyroid-binding globulin but normal cortisol binding. J. clin. Endocr., 22, 11651170.

4) Bernstein, G. \& Oppenheimer, J.H. (1966) Factors influencing the concentration of free and total thyroxine in patients with nonthyroidal disease. J. clin. Endocr., 26, 195-201.

5) Braverman, L.E., AvRuskin, T., Cullen, M.J., Vagenakisis, A.G. \& Ingbar, S.H. (1971) Effects of norethandrolone on the transport and peripheral metabolism of thyroxine in patients lacking thyroxine-binding globulin, observation on the physiological role of thyroxine-binding prealbumin. J. clin. Invest., 50, 1644-1649.

6) Cavalieri, R.R. (1961) Hyperthyroidism and decreased thyroxine binding by serum proteins. J. clin. Endocr., 21, 1455-1468.

7) Cavalieri, R.R. \& Searle, G.L. (1966) The kinetics of distribution between plasma and liver of ${ }^{131}$ I-labeled L-thyroxine in man: observations of subjects with normal and decreased serum thyroxine-binding globulin. J. clin. Invest., 45, 939-949.

8) Cavalieri, R.R., Steinberg, M. \& Searle, G.L. (1970) The distribution kinetics of triiodothyronine: studies of euthyroid subjects with decreased plasma thyroxinebinding globulin and patients with Graves' disease. J. clin. Invest., 49, 1041-1050.

9) Cavalieri, R.R., Steinberg, M. \& Searle, G.L. (1971) Metabolic clearance rate of Ltriiodothyronine in man; a comparison of results by single-injection and constant infusion methods. J. clin. Entacr., 33, 624-629.

10) Christensen, L.K. \& Litonjua, A.D. (1961) Is thyroxine binding by pre-albumin of physiologic importance? J. clin. Endocr., 21, 104-106.

11) Demura, R., Saito, S., Demura, H., Sakurada, T., Tayama, S., Nunokawa, T. \& Miura, K. (1969) Radioimmunoassay of TSH. Folia endocr. jap. (Jap.), 45, 1400 (abstract).

12) Diekmann, W.J. (1952) The Toxemias of Pregnancy. St. Louis, C.V. Mosby Co., pp. 101-102.

13) Dowling, J.T., Freinkel, N. \& Ingbar, S.H. (1960) The effect of estrogens upon the peripheral metabolism of thyroxine. J. clin. Invest., 39, 1119-1130.

14) Florsheim, W.H., Dowling, J.T. Meister, L. \& Bodfish, R.E. (1962) Familial elevation of serum thyroxine-binding capacity. J. clin. Endocr., 22, 735-740.

15) Heinonen, O.P., Lamberg, B.-A. \& Virtamo, J. (1970) Inherited decrease of the binding capacity of thyroxine-binding globulin (TBG). Acta endocr. (Kbh.), 64, 171180.

16) Hennemann, R. \& Dolman, A. (1971) Relationship between total thyroxine and absolute free thyroxine and the influence of absolute free thyroxine on thyroxine disposal in humans. J. clin. Endocr., 33, 63-67.

17) Hennen, G., Pierce, J.G. \& Freychet, P. (1969) Human chorionic thyrotropin: further characterization and study of its secretion during pregnancy. J. clin. Endocr., 29, 581-594.

18) Hotellung, D.R. \& Sherwood, L.M. (1971) The effects of pregnancy on circulating triiodothyronine. J. clin. Endocr., 33, 783-786.

19) Ingbar, S.H. (1961) Clinical and physiological observations in a patient with an idiopathic decrease in the thyroxine-binding globulin of plasma. J. clin. Invest., 40, $2053-2063$.

20) Ingbar, S.H. \& Freinkel, N. (1955) Simultaneous estimation of rates of thyroxine degradation and thyroid hormone synthesis. J. clin. Invest., 34, 808-819. 
21) Ingbar, S.H. \& Freinkel, N. (1960) Regulation of the peripheral metabolism of the thyroid hormones. Rec. Progr. Hormone Res., 16, 353-403.

22) Ingbar, S.H., Wterhourse, W.C. \& Cushman, P. (1964) Observations on the nature of the underlying disorder and the occurrence of associated plasma transport abnormalities in a patient with an idiopathic increase in the plasma thyroxine-binding globulin. $J$. clin. Invest., 43, 2266-2271.

23) Jones, J.E. \& Seal, U.S. (1967) X-chromosome linked inheritance of elevated thyroxine-binding globulin. J. clin. Endocr., 27, 1521-1528.

24) Katz, C.F.H. \& Oppenheimer, J.H. (1963) Idiopathic elevation of serum thyroxinebinding alpha-globulin capacity: report of a case and comment on incidence. Aerospace Med., 34, 1152-1153.

25) Kraemer, E. \& Wiswell, J.G. (1968) Familial thyroxine-binding globulin deficiency. Metabolism, 17, 260-262.

26) Levy, R.P., Marshall, J.S. \& Velayo, N.L. (1971) Radioimmunoassay of human thyroxine-binding globulin (TBG) J. clin. Endocr., 32, 372-381.

27) MeConnon, J., Row, V.V. \& Volpé, R. (1972) The influence of liver damage in man on the distribution and disposal rates of thyroxine and triiodothyronine. $J$. clin. Endocr., 34, 144-151.

28) Musa, B.U., Kumar, R.S. \& Dowling, J.T. (1969) Role of thyroxine-binding globulin in the early distribution of thyroxine and triiodothyronine. J. clin. Endocr., 29, $667-674$.

29) Nikolai, T.F. \& Roberts, R.C. (1969) Thyroxine binding globulin (TBG) deficiency. Arch. intern. Med., 124, 691-694.

30) Nusynowiz, N.L., Clark, R.F., Strader, W.J., Estrin, H.M. \& Seal, U.S. (1971) Thyroxine-binding globulin deficiency in three families, and total deficiency in a normal woman. Amer. J. Med., 50, 458-464.

31) Oddie, T.H., Fisher, D.A., Dussault, J.H. \& Thompson, C.S. (1971) Triiodothyronine turnover in euthyroid subjects. J. clin. Endocr. 33, 653-660.

32) Oppenheimer, J.H., Bernstein, G. \& Hasen, J. (1967) Estimation of rapidly exchangeable cellular thyroxine from the palsma disappearance curves of simultaneously administered thyroxine-131 $\mathrm{I}$ and albumin-125. J. clin. Invest., 46, 762-777.

33) Oppenheimer, J.H., Martinez, M. \& Bernstein, G. (1966) Determination of the maximal binding capacity and protein concentration of thyroxine-binding prealbumin in human serum. J. Lab. clin. Med., 67, 500-509.

34) Refetoff, S., Robin, N.I. \& Alpзr, C.A. (1972) Study of four new kindreds with inherited thyroxine-binding globulin abnormalities, possible mutations of a single gene locus. J. clin. Invest., 51, 848-867.

35) Rosenbaum, J.M., Krieg, A.F., Henry, J.B., Mozley, J.M. \& McAfee, J.G. (1968) Thyroid function evaluation in patients with increased or decreased thyroxine-binding protein. Amer. J. clin. Path., 50, 336-343.

36) Sakurada, T., Saito, T., Inagaki, K., Tayama, T. \& Torikai, T. (1967) Polyacrylamide gel electrophoratic study on the effect of estrogen on human thyroxine-binding prealbumin. Tohoku J. exp. Med., 93, 339-362.

37) Sakurada, T., Saito, S., Inagaki, K., Tayam?, S. \& Torikai, T. (1968) Concentration and binding capacity of thyroxine-binding prealbumin in pregnancy, hyper- and hypothyroidism. Tohoku J. exp. Med., 96, 259-266.

38) Sakurada, T., Saito, S., Inagaki, K., Tayama, T. \& Torikai, T. (1969) Quantitative determination of total and free triiodothyronine and thyroxine. Tohoku J. erp. Med., 99, 179-188.

39) Sakurada, T., Saito, S. Yamaguchi, T., Yamamoto, M., Demura, R., Demura, H., Fukuchi, S., Yoshida, K. \& Torikai, T. (1973) Radioimmunoassay of triiodothyronine. Tohoku J. exp. Med., 110, 329-340.

40) Shane, S.R., Seal, U.S. \& Jones, J.H. (1971) X-chromosome linked inheritanca of elevated thyroxine-binding globulin in association with goiter. J. clin. Entocr., 32, $587-594$. 
41) Sterling, K. \& Hegedus, A. (1962) Measurement of free thyroxine concentration in human serum. J. clin. Invest., 41, 1031-1040.

42) Sterling, K. \& Tabachnick, M. (1961) Paper electrophoretic demonstration of thyroxine-binding prealbumin fraction in serum. Endocrinology, 68, 1073-1075.

43) Tanaka, S. \& Starr, P. (1959 a) A euthyroid man without thyroxine-binding globulin. J. clin. Endocr., 19, 485-487.

44) Tanaka, S. \& Starr, P. (1959 b) Clinical obsrvation on serum globulin thyroxinebinding capacity, using a simplified technique. J. clin. Endocr., 19, 84-91.

45) Thomson, J.A., Meredith, F.M., Baird, S.G., McAinsh, W.R. \& Hutchison, J.H. (1972) Raised free thyroxine value in patients with familial elevation of thyroxine-binding globulin. Quart. J. Med., 16, 49-56.

46) Woeber, K.A., Hecker, E. \& Ingbar, S.H. (1970) The effects of an acute load of thyroxine on the transport and peripheral metabolism of triiodothyronine in man. $J$. clin. Invest., 49, 650-654.

47) Zaninovich, A.A., Volpé, R. \& Ezrin, C. (1969) Effects of variations of thyroxinebinding globulin capacity on the disappearance of triiodothyronine from the plasma. J. clin. Endocr., 29, 1601-1607. 